\title{
Feasibility Study on Small Scale Food Production Using Off-Grid Photovoltaic Water Pumping System in Coastal Dune
}

\author{
Xinyan Wang ${ }^{1}$, Kotaro Tagawa ${ }^{2 *}$ and Bateer Baiyin ${ }^{3}$ \\ ${ }^{1}$ Faculty of Regional Sciences, Tottori University, Japan \\ ${ }^{2}$ Faculty of Agriculture, Tottori University, Japan \\ ${ }^{3}$ Department of Dryland Science, Graduate school of Sustainability Science, Tottori University, Japan \\ *Corresponding author: Kotaro Tagawa, Faculty of Agriculture, Tottori University, Japan, Email: tagawa@tottori-u.ac.jp
}

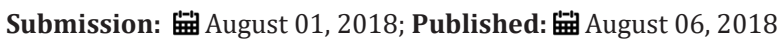

\begin{abstract}
A small-scale food production which is combined an off-grid photovoltaic water pumping system with vegetable cultivation was tested. The groundwater at seashore in coastal dune are irrigated to cultivate Swiss chard. The practicability of off-grid photovoltaic water pumping system and availability of groundwater in coastal dune are suggested.
\end{abstract}

Keywords: Off-grid photovoltaic system; Water pumping; Coastal groundwater; Food production; Developing country; Arid region

\section{Introduction}

Approximately 795 million people in the world suffer from malnutrition and most of the population is living in developing countries and in arid region [1]. Small and family farming are main form of food production in the countries and region with high malnutrition rate, but the limited land use and the lack of access to water and energy resources hinder to enhance the supply of nutrient by sustainable food production. Facing these issues, smallscale food production system with consideration of relationship between food, energy and water supply has been attracting a lot of attention in recent years [2,3]. From this background, this study aims to develop the small-scale food production system which is combined photovoltaic (PV) water pumping system with cultivation of vegetable. Specially, groundwater at seashore in coastal dune is considered as new water resource for food production. The results of demonstration test of PV water pumping system and cultivation of vegetable are reported in this paper.

\section{Material and Method}

The schematic diagram of experimental system is shown in Figure 1. The experimental system was installed at coastal dune located in the Arid Land Research Center, Tottori university, JAPAN. In Figure 1a, a well for intake of groundwater was constructed at the distance of $30 \mathrm{~m}$ from the seashore. The diameter and depth of well were $0.5 \mathrm{~m}$ and $5.5 \mathrm{~m}$. The groundwater was supplied for the cultivation using drip irrigation in the greenhouse where was located far from seashore at a distance of $740 \mathrm{~m}$. Firstly, the groundwater was pumped up to water tank I at the hillside of dune by the submerged pump(SHURflo, 9325-043-101), and then it was pumped up to water tank II installed at the hilltop of dune by the water pump(SHURflo, Blaster 3901-2204). Finally, the groundwater in water tank II was supplied to a greenhouse from the hilltop by gravity.
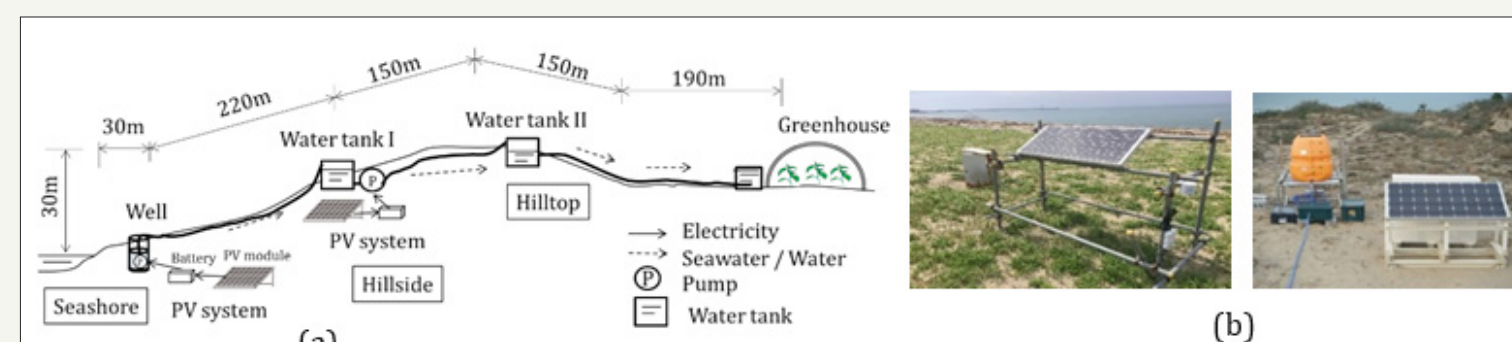

(a)

(b)

Figure 1: Schematic diagram of experimental system: (a) configuration of experimental apparatus, (b) off-grid photovoltaic system installed at seashore and hillside of coastal dune. 
In Figure 1b, two off-grid PV systems were installed at the seashore and the hillside of dune. Each off-grid PV system was composed of a PV module (K.I.S., AS140), a battery (GS YUASA, SEB100), and a controller for charging and discharging (Well See, WS-MPPT15). The maximum output of each PV module was $140 \mathrm{~W}$ and the capacity of battery was $100 \mathrm{Ah}$ at voltages of $12 \mathrm{~V}$. The pumps were driven at the DC voltage of $12 \mathrm{~V}$ and were driven from 8:00-16:00 every day. The operation of submerged pump in every hour was included an execution of water pumping for 45 minutes followed by a suspension for 15 minutes, while the operation of water pump was included an execution of water pumping followed by a suspension for 45 minutes.

In case of crop cultivation in greenhouse, six ridges with length of $10 \mathrm{~m}$ and width of $0.6 \mathrm{~m}$ were formed and the total irrigation area was $36 \mathrm{~m}^{2}$. Swiss chard was cultivated in this experiment. The range of electric conductivity of groundwater in the well was from 0.18 to $0.41 \mathrm{mS} / \mathrm{cm}$ in the experiment period of this study. The irrigation time was 50 minutes from 6 A.M. every day, and water of 149L was used for irrigation. Field experiment was carried out for 44 days (from 7th September to 20th October, 2017).

\section{Result and Discussion}

Typical results of the field experiment on water pumping and vegetable cultivation are shown in Table 1 . From these results of Table 1, it is realized most of electric power generation is spent for water pumping because the ratio of electric power consumption to electric power generation of PV system reaches to roughly $90 \%$. On the other hand, the ratio of water consumption for irrigation to amount of pumped saline groundwater is about $30 \%$. Since the capacity of irrigation water per day of $497.5 \mathrm{~L} /$ day is conducted from the amount of pumped groundwater for the period of field experiment, the total amount of pumped groundwater by the developed system is predicted to be enough to cultivate Swiss chard for the irrigation area of $60 \mathrm{~m}^{2}$. Moreover, assuming that recommended average daily intake amounts of dark-green vegetable is $237 \mathrm{~g} /$ day for a family of two adults and two children [3], it is estimated the amount of harvested Swiss chard in the experiment is nearly equivalent to the intake amount of darkgreen vegetable that the assumed family consumes for 50 days. From these results, it is shown that the groundwater at seashore in coastal dune is effective to irrigate vegetable cultivation in case that the concentration of irrigated groundwater is one-fiftieth times as much as that of seawater in this experiment. It is also considered an off-grid PV water pumping system is useful to obtain water resource for small-scale food production. As next step, it must be necessary to find the optimum design of PV system in consideration of installation and operation costs.

Table 1: Typical Results of field experiment on groundwater pumping and vegetable cultivation for 44 days.

\begin{tabular}{|c|c|}
\hline List of Measurements & Results \\
\hline Electric power generation of PV system & $6.67 \mathrm{kWh}$ \\
\hline Electric power consumption of water pumping & $5.99 \mathrm{kWh}$ \\
\hline Amount of pumped saline groundwater & $21.89 \mathrm{~m}^{3}$ \\
\hline Water consumption for irrigation & $6.66 \mathrm{~m}^{3}$ \\
\hline Amount of harvested Swiss chard & $13.62 \mathrm{~kg}$ \\
\hline
\end{tabular}

\section{Conclusion}

Feasibility study on small-scale food production combing the vegetable cultivation with photovoltaic water pumping system has been performed in coastal dune. From the experimental results, electric power supply and consumption for the operation of off-grid photovoltaic water pumping system are evaluated. It is also suggested the groundwater in coastal dune is available for vegetable cultivation.

\section{Acknowledgement}

This study has been funded by the International Platform for Dryland Research and Education. This study has been also supported partly by Japan Science and Technology Agency (JST)/ Japan International Cooperation Agency (JICA), Science and Technology Research Partnership for Sustainable Development (SATREPS) program.

\section{References}

1. Rasul G (2016) Managing the food, water, and energy nexus for achieving the sustainable development goals in South Asia. Environmental Development 18: 14-25.

2. Helmstedt KJ, Stokes Draut JR, Larsen AE, Potts MD (2018) Innovating at the food, water, and energy interface. Journal of Environmental Management 209: 17-21.

3. Ebrahim K, Somayeh A, Mohtar R, Baawain M (2018) Towards the optimization of sustainable food-energy-water systems. Journal of Cleaner Production 171: 662-674.
Creative Commons Attribution 4.0 International License

For possible submissions Click Here

\section{Submit Article}

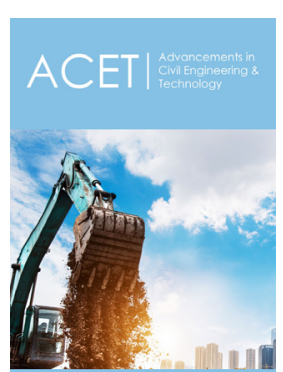

Advancements in Civil Engineering \& Technology

\section{Benefits of Publishing with us}

- High-level peer review and editorial services

- Freely accessible online immediately upon publication

- Authors retain the copyright to their work

- Licensing it under a Creative Commons license

- Visibility through different online platforms 